\title{
Validity and Effectiveness of Argument-Driven Inquiry Model with Contextual Approaches to Improve Critical Thinking Skills in Science Learning
}

\author{
*S Fadilah. MS1, B Jatmiko², T Prastowo² \\ 1Science Education Study Program, Postgraduate Program, Universitas Negeri Surabaya, Surabaya 60213, Indonesia \\ 2Department of Physics, Faculty of Mathematics and Natural Science, Universitas Negeri Surabaya, Surabaya 60231, \\ Indonesia
}

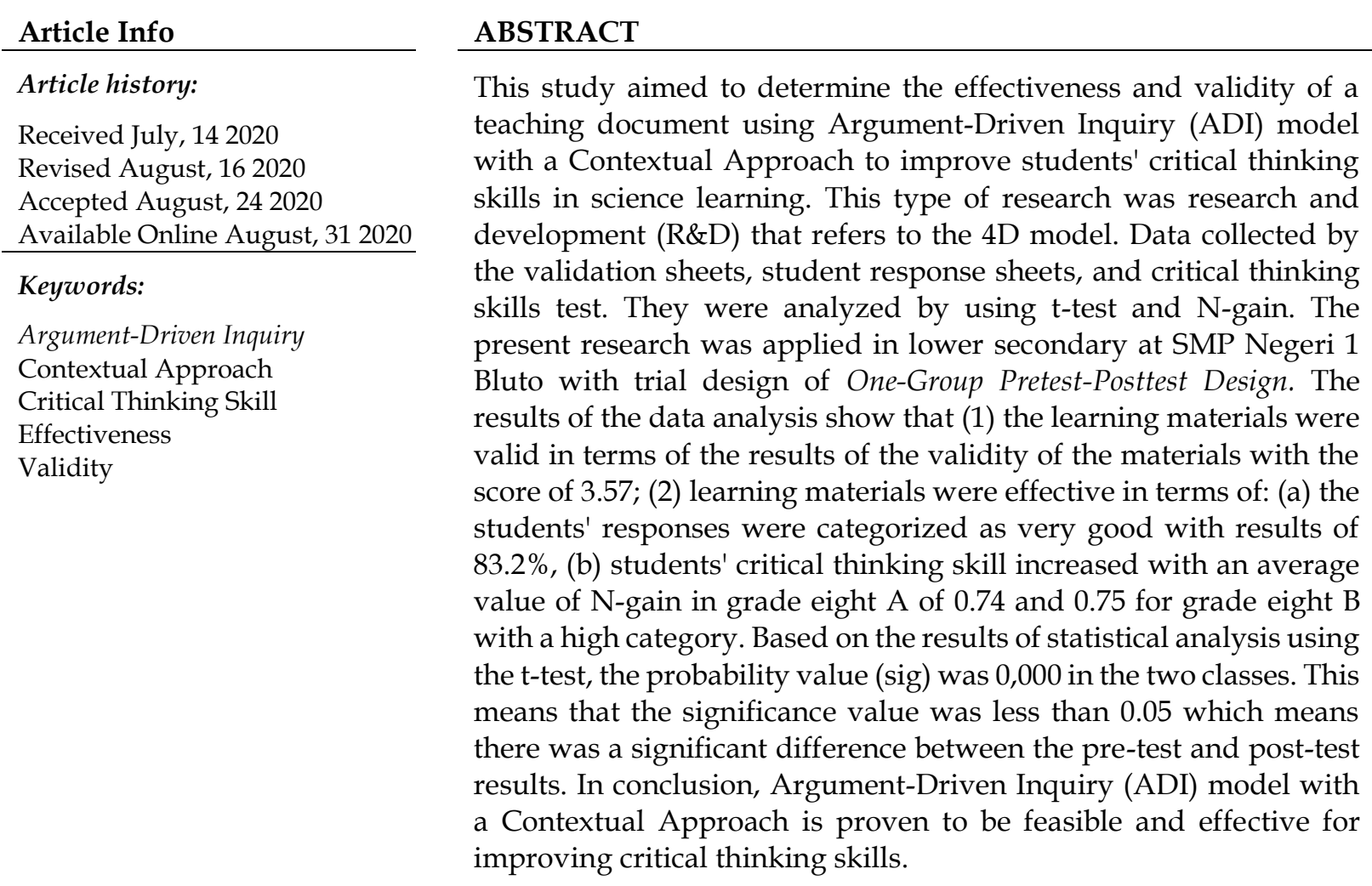

https://doi.org/10.46627/silet

\section{INTRODUCTION}

As an essential subject in education, Science has an important role in improving the quality of education in Indonesia. In Science, students are required to have high order thinking skills (HOTS) to be able to master the material. Science learning requires high critical thinking skills thus, students can develop the ability to think logically and creatively to create Human Resources (HR) who have the skills needed in the future workforce. This is what underlies the importance of critical thinking skills in life. This is supported by the fact that education in the 21st century requires human resources with competencies and achievements directed at learning abilities and innovations. This includes the ability to think critically, solve problems, make decisions, think creatively, be responsible, and learn independently (Griffin \& Care, 2015). Critical thinking skills have the potential to form quality human beings for these skills highly important in helping one to solve problems, make decisions, choose the desire to understand and comprehend. Science learning also requires students to have high analytical and evaluation skills in solving every problem. This is why critical thinking skills are needed. The ability to think critically is the ability 
of students to analyze and evaluate information to decide whether the information can be trusted so that it can be used to draw a valid conclusion.

Facione (2011) states that critical thinking is self-regulation in deciding something that results in interpretation, analysis, evaluation, and inference. Choy \& Cheah (2009) defines critical thinking as a complex process that requires quite high cognitive processing of information. Facione (2011) suggested that there are 10 indicators of critical thinking. Based on preliminary research conducted it is known that critical thinking of junior high school students is still low. So, in this study, the researchers took five indicators to describe students' critical thinking skills. These include skills of analysis, evaluation, interpretation, inference, and explanation. That indicator was chosen because its result of preliminary research is still low and easily observed and easily measured.

Science learning should be a vehicle for students to find out and learn the natural surroundings directly. In fact, Indonesia's achievements in science subjects are still low. A study conducted by the International Program for Student Assessment (PISA) in 2018 showed that the average results in the field of Science decreased when compared to PISA in 2015. In 2015 the average value of science was 402 points while in PISA 2018 the average value science 396 points. This means students are only able to recognize or identify explanations about simple scientific phenomena but have not been able to use various information, explain evidence and arguments using critical analysis, and have not been able to demonstrate the ability to think and reason scientifically. Indonesia ranked 70th out of 78 countries, meaning that it is only able to be at an average level 1 (Schleicher, 2019). This is supported by the results of research conducted by Nufus, Rosidin, \& Hasnunidah (2018) through a test instrument developed by Ennis (2011) which shows that the critical thinking ability of junior high school students is still low. The indicators in this study are analysis, interpretation, explanation, inference, evaluation, and based on the results of preliminary studies by researchers, these indicators are still low covering analysis indicators $19.71 \%$; explanation $31.72 \%$; interpretation of $11.54 \%$; evaluation of $18.27 \%$ and inference $18.27 \%$.

Based on these problems, a solution is needed to improve students' thinking skill. One of the solutions is the development of science teaching document that lead to the improvement of critical thinking skill (Hasnunidah, Susilo, Henie, \& Sutomo, 2015). Development of teaching document using the ADI Model is expected to improve students' critical thinking skill. The advantage of the ADI Model are gives students the opportunity to design their research and find their own research result. Students will be involved a lot in the argumentation process where they can share and support their ideas. ADI model is an effective model to improve students' communication and writing skills, and invites students to experience the process of forming their knowledge (Demircioglu \& Ucar, 2015). Besides learning using ADI model also involves student in conducting investigations, so making it easier for the learning process (Van Uum, Verhoeff, \& Peeters, 2016). According to Yacoubian \& Khishfe (2018) the skills of argumentation is an important component in making decision and revealed that the skills of argumentation can support students in developing understanding of information knowledge. So that the ADI model is expected to improve students' thinking skills.

In addition to using the ADI model, contextual approaches needed to improve critical thinking skill. Contextual approach is an educational process that aims to help students see meaning in the work material they learn by connecting with the context of everyday life. Contextual learning can foster students' metacognitive skills which are an important component in science learning (Dori, Avargil, Kohen \& Saar, 2018). Teaching materials with ADI Model and Contextual Approach is expected to help the teaching and learning process and know the level of students' thinking skill. In the end, students can achieve the specified competencies and can gain a meaningful learning experience.

Currently, learning is conducted with lecture and discussion methods. In the present research ADI learning model is combined with contextual approach that students easily associated it with daily life is an alternative and innovative solution to improve students' critical thinking skill. 
Therefore, the focus of this research was to produce the validity and effectiveness of learning materials using Argument-Driven Inquiry model with contextual approach to improve students' critical thinking skills. Based on this research focus, it is necessary to determine the validity and effectiveness of learning materials using the ADI model with contextual approach to improve students' critical thinking skills.

\section{RESEARCH METHOD}

\section{General Background}

This research was conducted at Bluto 1 Junior High School, Sumenep in February-March 2020. The scope of this study was students of grade eight academic year 2019-2020 school year. This is a development research that refers to the $4 \mathrm{D}$ model. This research was conducted in two phases, the development stage of learning material adapted to the $4 \mathrm{D}$ model covering 4 stages (Thiagarajan \& Semmel, 1974) with modifications, i.e. the define, design, develop, and dissemination, for more details, see figure 1.

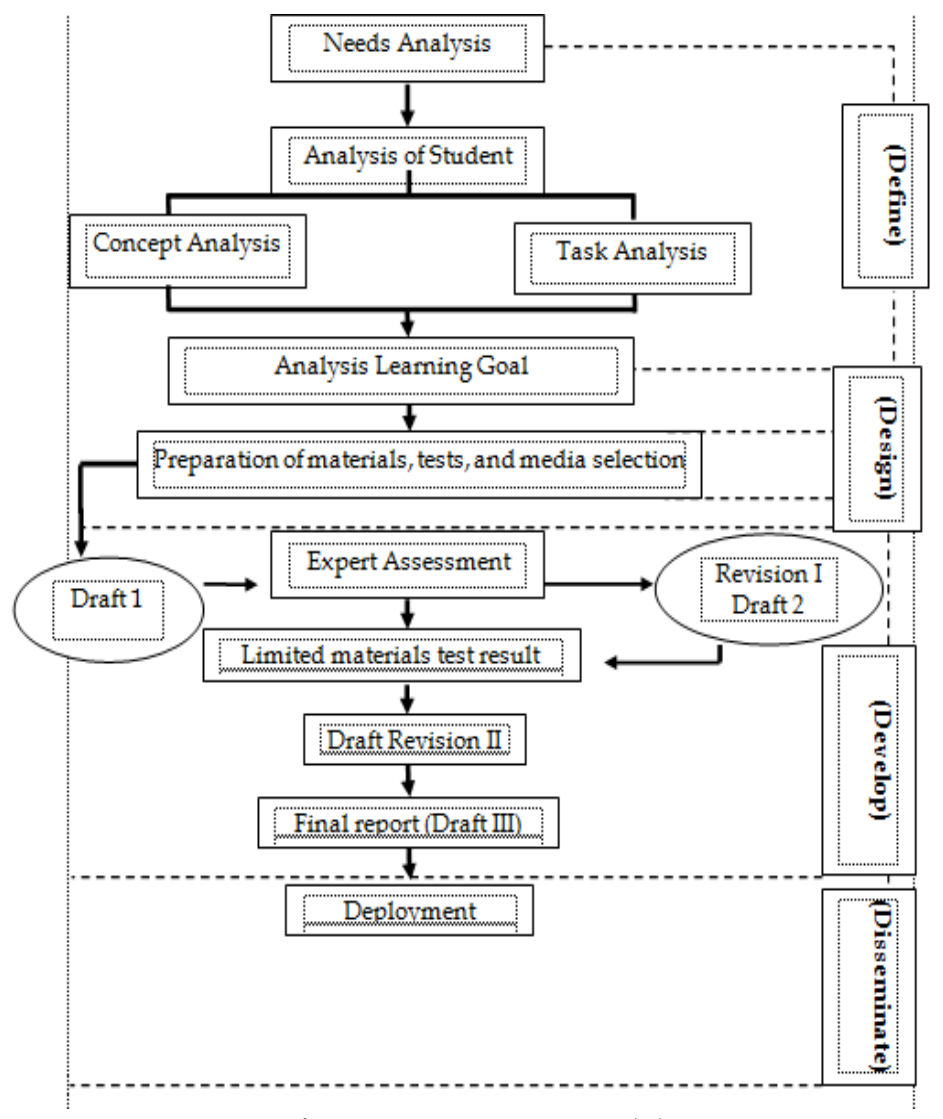

Figure 1. Four-D Model

Analysis conducted in this study namely defining stage which included needs analysis, student analysis, task analysis, concept analysis, and formulation of learning objectives; the next stage of designing includes the preparation of tests, media selection, and formation; the third stage of developing included validation by experts, trials and the disseminate. The implementation phase in the classroom used a One-Group Pretest-Posttest Design. It emphasized on the analysis of the validity and effectiveness of the ADI model with a contextual approach to improve students' critical thinking skill on the topic of Pressure.

\section{Sample/Participants}

This research was tested at SMPN 1 Bluto (Sumenep) in the even semester, 2019/2020 academic year with four with for meetings. The subjects of this study were tested in 2 classes with a total of 53 students with 27 students from grade eight A and 26 students from grade eight $B$. 


\section{Instrument and Procedures}

This study used a One-Group Pretest-Posttest Design. This research was carried out based on the following steps:

1. Preparation: At this stage the researcher developed teaching materials which include lesson plans, handouts, Student worksheet (LKPD), and the Critical Thinking skills Test. Then the expert validity was conducted by the validator.

2. Implementation: This stage is carried out four times face to face. Pre-test was given before treatment while post-test is given after treatment. To find out students' responses during learning, a questionnaire was used.

\section{Data Analysis}

The data analysis technique of the study was the validity test by two expert validators. The value of N-gain was then calculated. The normality test in this study was calculated using SPSS software version 16. Significance $<0.05$ means $\mathrm{H}_{0}$ is rejected and $\mathrm{H}_{1}$ is accepted. Conversely, if the significance value is $\geq 0.05$ then $\mathrm{H}_{0}$ is accepted and $\mathrm{H}_{1}$ is rejected. This also applies for homogeneity test. Hypothesis test was carried out by paired $t$ test. Criteria for acceptance or rejection of the hypothesis in this study if sig $\geq 0.05$ or $t_{\text {count }}<t_{\text {table }}$ means $\mathrm{H}_{0}$ is accepted, whereas if sig $<0.05$ or $t_{\text {count }} \geq t_{\text {table }}$ then $\mathrm{H}_{1}$ is accepted.

\section{RESULTS AND DISCUSSION}

\section{A. The validity of the ADI Model Device with a Contextual Approach}

Teaching instruments and research instruments must meet the requirements of validity and reliability prior to a research. Four types of teaching materials include lesson plans, handouts, worksheets, and critical thinking skill tests. The validity of the learning materials was assessed by two experts as validators. Validation results are presented in Table 1.

Table 1 . Validation Results of The Learning Materials

\begin{tabular}{lccclcc}
\hline \multirow{2}{*}{ Type of learning device } & \multicolumn{2}{c}{ Validation score } & \multirow{2}{*}{ Average } & \multirow{2}{*}{ Categories } & \multirow{2}{*}{ Reliability } & \multirow{2}{*}{ Categories } \\
\cline { 2 - 3 } & $\boldsymbol{V} \mathbf{1}$ & $\mathbf{V} \mathbf{2}$ & & & & \\
\hline Lesson Plan & 3.84 & 3.37 & 3.61 & Very valid & 87.27 & Reliable \\
\hline Handout & 3.67 & 3.33 & 3.50 & Valid & 91.27 & Reliable \\
\hline Student's Worksheet (LKPD) & 3.61 & 3.44 & 3.53 & Valid & 91.52 & Reliable \\
\hline Critical thinking skill tests & 3.86 & 3.43 & 3.64 & Very valid & 94.05 & Reliable \\
\hline Total Average & 3.74 & 3.39 & 3.57 & Valid & 91.03 & Reliable \\
\hline
\end{tabular}

Table 1 shows that the validity of the lesson plan obtained a score of 3.61 with a very valid category with a reliability value of $87.27 \%$. The learning plan used has met the validity. The learning plan used has been planned systematically that learning run smoothly, pleasantly, effectively, and made students more active.

The handout was proven to be suitable for use with a valid category of 3.50 with a reliability of $91.27 \%$. One of the goals of Handouts use for students in the learning process according to Prastowo (2012) is to accompany the teacher's explanation and help students not to record and focus on learning. Handouts are tailored to the needs of students who are used as a source of information to solve the problems given on the student worksheet. The use of handouts can spur new students' enthusiasm to be involved in the learning process (Anderson, 2001).

Worksheets are feasible to be used as a means of interaction between students in solving problems related to the ADI model with contextual detection. The average score of students' worksheet validity was 3.53 with a valid category and reliability was $91.52 \%$. The students' worksheet could assist students in conducting observational activities or practicum during the learning process.

Critical thinking skills tests were arranged to measure the five indicators of critical thinking skills including explanation, interpretation, analysis, inference, and evaluation (Facione, 2011). 
The test was feasible to be used for application with an average score of validity of 3.64 with a very valid category and a Reliability score of $94.05 \%$.

\section{B. Students' Responses}

Student responses are responses to the science learning process using the ADI model and the contextual approach obtained using a questionnaire. The questionnaire was filled out by all students at the end of the lesson. Based on the data, the results of student questionnaire responses to science learning using the ADI model with an average contextual approach are in the very good category with an average score of $83.2 \%$. The results of students' responses to each indicator are presented in Figure 1.

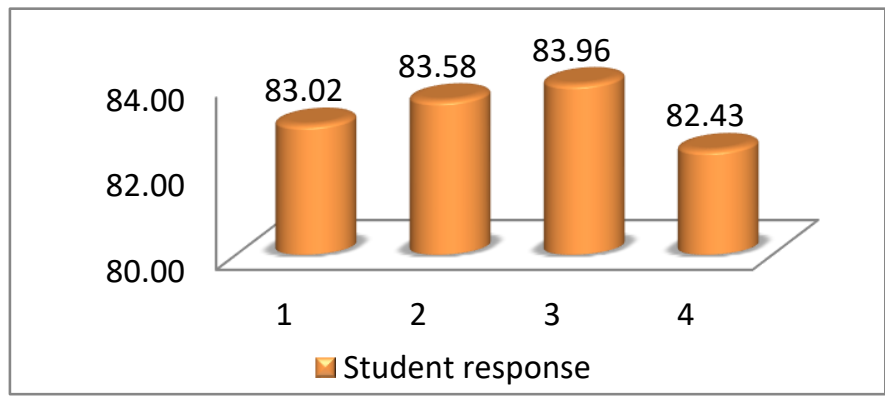

Figure 1. Student Responses

Statement:

1 : Student interest in the learning model used,

2 : Clarity of material, tasks, and learning model used,

3 : Students' encouragement of science learning with the model used,

4 : Student satisfaction with the learning model used,

The first response indicator, such as student interest in the learning model obtained a score of $83.02 \%$, the second indicator was the clarity of the material, assignments, and models used during the learning process with a score of $83.58 \%$. This is in accordance with Ausubel's Meaningful Learning theory that subject matter is more easily understood if it is in accordance with cognitive structure and scientific structure, and includes the linkages of all materials (Abdullah, 2013). The third indicator is the encouragement of students towards learning science with the model used a score of $83.96 \%$. The third indicator obtained highest response. This is in line with research conducted by Peşman \& Özdemir (2012) that the influence of a contextual approach on student achievement and interest depends on the learning model and method applied. The use of ADI model encourages students to study science more actively. The fourth indicator was student satisfaction with the learning model used with an average score of $82.43 \%$.

Based on the acquisition of each indicator score, ADI model received a good response. The teacher succeeded in choosing the right learning model. This is also in line with one of the strengths of the ADI model that it can help students in the learning process and can attract students' interests especially in expressing (Demircioglu \& Ucar, 2015). Djamarah (2011) stated that teachers must have a strategy so that students can learn effectively and efficiently. Variations in learning models used by teachers could attract students' interest from boredom during learning because learning was more student-centered, this made students more enthusiastic in learning. This is supported by research conducted by Aditomo \& Klieme (2020) that inquirybased models had a positive impact on student learning outcomes because of student-centered learning.

\section{Critical Thinking Skills}

Students' critical thinking skills were measured by conducting a critical thinking test. A total of 10 items of questions were used in the critical thinking ability test in the form of description. 
The test of critical thinking skills referred to the indicators of critical thinking put forward by Facione (2011) which includes the ability to analyze, evaluate, explain, inference and interpret. The critical thinking ability test was carried out twice before and after learning.

Harris, Phillips, \& Penuel (2012) suggested that the main part of the learning process involving various important aspects including formulating questions, describing mechanisms and building arguments. Arguments or opinions can train students to use their thinking skill. Arguments, according to Deane, \& Song (2014) have an important role in developing critical thinking patterns and adding a deep understanding of an idea. To test students' critical thinking skill, the questions arranged were designed to make students answered as expected. The result of critical thinking skill are seen from the increase in the result of pre-test and post-test learning using the ADI model with a contextual approach. They are presented in Figure 2 and Figure 3.

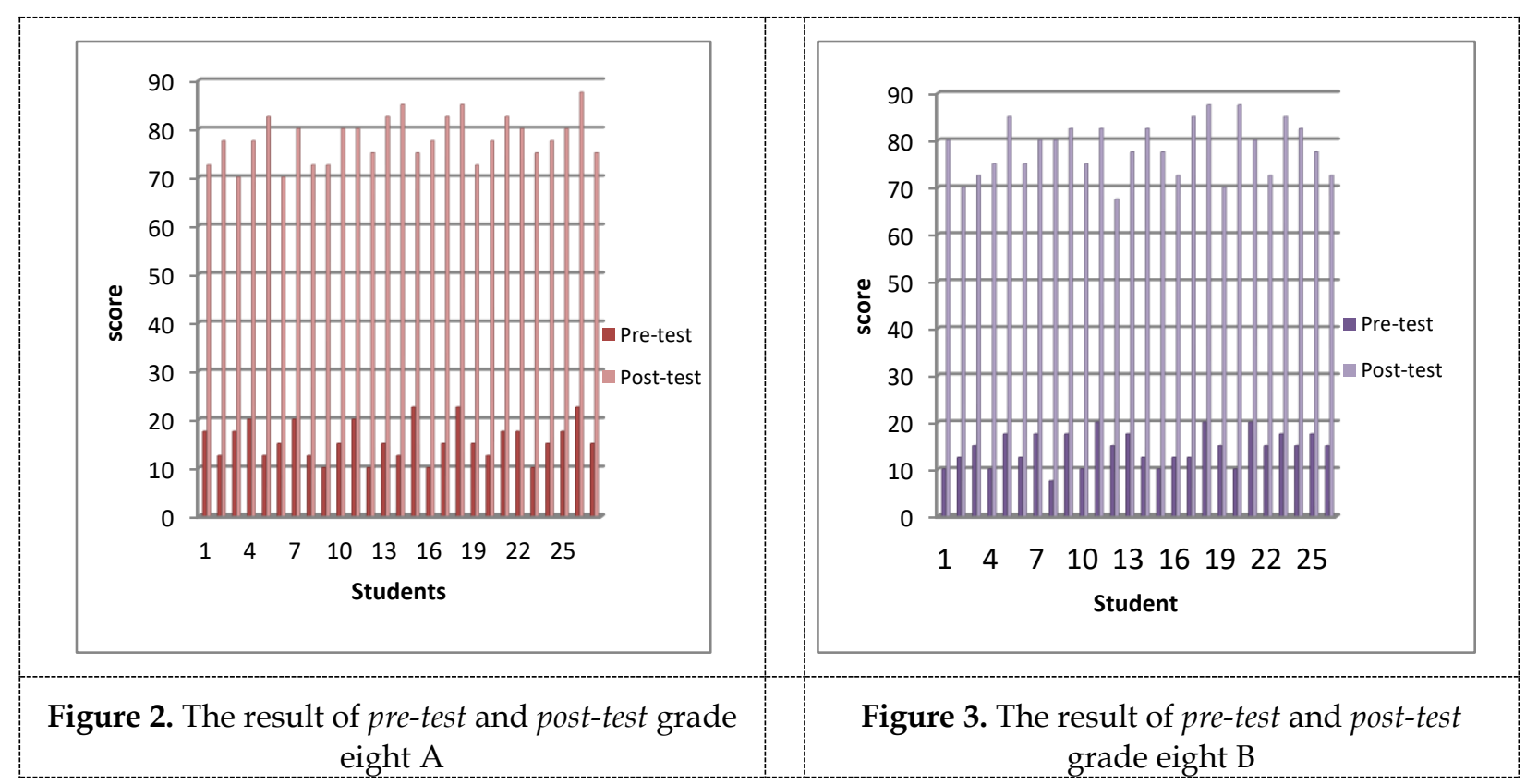

The students' score increased before and after learning using ADI model with a contextual approach. To determine the effect of the learning process with the ADI model on students' critical thinking abilities $\mathrm{N}$-gain calculations were performed. The results of the $\mathrm{N}$-gain calculation are presented in Figure 3.

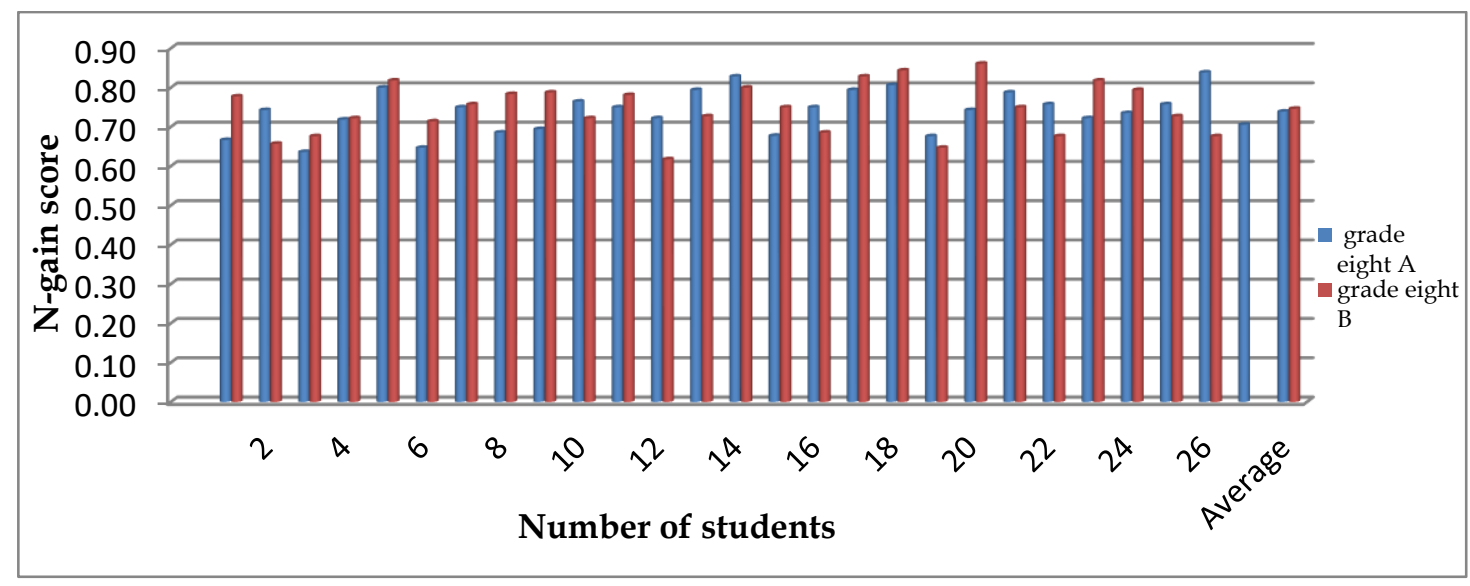

Figure 3. N-gain Scores of students for grade eight $A$ and grade eight $B$

The $\mathrm{N}$-gain in grade eight $\mathrm{A}$ was 0.74 while the average $\mathrm{N}$-gain in grade eight $\mathrm{B}$ is 0.75 with a high category. A total of 53 students consisting of 27 students of grade eight A and 26 students of 
grade eight $B$ took pre-test and post-test. In grade eight A, 7 students were in the medium category and 20 students in the high category. In grade eight $B$ there were 7 students in the medium category and 19 other students in the high category. This shows that students used critical thinking skills through the ADI learning model with the contextual approach applied in learning.

This is in line with Sampson \& Walker (2012) opinion that ADI is a learning model designed to change conventional learning that makes students have the opportunity to learn in scientific inquiry in a reflective manner so that they can develop their argumentative and critical thinking skills. The increase in the medium category was caused by several factors including: (1) the absence of continuous efforts to improve students' critical thinking skills in the learning process; (2) students are not familiar with the questions that require critical thinking; (3) time limitations in evaluating critical thinking skills. Data analysis in this study used SPSS version 16 . The results of the N-gain normality test of grade eight A and eight B can be seen in table 2 and 3.

$\frac{\text { Table 2. Normality Test of grade eight } A}{\text { Shapiro-Wilk }}$

\begin{tabular}{|c|c|c|c|}
\hline & Statistic & $\overline{\mathrm{Df}}$ & Sig. \\
\hline $8 A$ & .979 & 27 & .829 \\
\hline
\end{tabular}

Table 3. Normality Test of grade eight $B$

\begin{tabular}{cccc}
\hline & \multicolumn{3}{c}{ Shapiro-Wilk } \\
\cline { 2 - 4 } $8 B$ & Statistic & Df & Sig. \\
\cline { 2 - 4 } & .977 & 26 & .793 \\
\hline
\end{tabular}

According to the test criteria, if the probability value (sig) $\geq 0.05$ then $\mathrm{H}_{0}$ is accepted and $\mathrm{H}_{1}$ is rejected. The above data shows that $\mathrm{N}$-gain grade eight $\mathrm{A}$ and grade eight $\mathrm{B}$ are normally distributed. Next Homogeneity Test can be seen in table 4 .

Tabel 4. Test of Homogeneity of Variance

\begin{tabular}{llcccc}
\hline & & Levene Statistic & df1 & df2 & Sig. \\
\hline Test of & Based on Mean & 1.633 & 1 & 51 & .207 \\
& Based on Median & 1.554 & 1 & 51 & .218 \\
& $\begin{array}{l}\text { Based on Median and with } \\
\text { adjusted df }\end{array}$ & 1.554 & 1 & 50.639 & .218 \\
& Based on trimmed mean & 1.613 & 1 & 51 & .210 \\
\hline
\end{tabular}

The $\mathrm{N}$-gain value obtained the probability value (sig) of 0.207 . According to the test criteria, if the probability value $(\mathrm{sig}) \geq 0.05$ then the null hypothesis $\left(\mathrm{H}_{0}\right)$ is accepted. This shows that the $\mathrm{N}$ gain data of students is homogeneous. Data analysis was performed using the two average similarity test, i.e. the paired $t$ test below;

Table 5. Paired t-Test eight $A$

\begin{tabular}{lrrrr}
\hline \multirow{2}{*}{ Pair 1} & \multirow{2}{*}{ Pretest-Posttest } & T & Df & Sig. (2-tailed) \\
\cline { 3 - 4 } & & -64.190 & 26 & 0.000 \\
\hline \multirow{4}{*}{ Table 6. Paired t-Test eight B } \\
\hline \multirow{2}{*}{ Pair 1} & \multirow{2}{*}{ Pretest-Posttest } & T & Df & Sig. (2-tailed) \\
\cline { 2 - 4 } & & -53.801 & 25 & 0.000 \\
\hline
\end{tabular}

Based on table 5 and table 6 there were differences in the results of pre-test and post-test results of students in grade eight $\mathrm{A}$ in science lessons, and there are differences in the results of pre-test 
and post-test results of students in grade eight B. This happened perhaps because ADI Model and contextual approach could help students improve their critical thinking skills. This result is supported by the theory of constructivism by Piaget that the theory of constructivism is a theory that considers the process of knowledge formation to occur gradually which is always faced with experiences or phenomena encountered by an individual (Sulistyowati, 2014).

One of the stages of the ADI Learning Model is the argumentation session. This is in line with Ausubel's Meaningful Learning theory that the learning process occurs if students can assimilate their knowledge with new knowledge learned so as to facilitate students in capturing material. This is also in line with the results of research conducted by Demircioglu \& Ucar (2015) which states that learning using the ADI model is more effective in improving academic achievement, argumentation skills, and science process skills compared to traditional methods. In addition, this is also supported by the results of other research conducted by Chen, Wang, Lin, \& Hong (2016) that learning using argument-based inquiry in the experimental class has a significant difference in the level of argumentation than in the control class. Bathgate, Crowell, Schunn, Cannady, \& Dorph (2015) states that the ability of high school students to make arguments in science has an impact on learning. In addition, it also supports the research results of Lubben, Sadeck, Scholtz, \& Braund (2010) who reported that there was an increase in the ability of argumentation in critical thinking through discussions conducted. The opinion of Demircioğlu \& Ucar (2012) in his research suggests that learning using the ADI model causes students' argumentation skills to change the significantly when compared to traditional methods. The opinion of Kadayifci, Atasoy, \& Akkus (2012) in his research states that the ADI model is recommended for use in the learning process in a laboratory.

\section{CONCLUSION}

The result of research and discussion concluded that the teaching of science using ADI model and contextual approach on topic of pressure to improve students' critical thinking skills are as follows: (1) Teaching device with ADI model and contextual approach to improve critical thinking skill was valid and reliable to be used with an average score of 3.57 and valid category. The teaching documents developed was reliable with a reliability score of $91.03 \%$; (2) Students' responses to the learning component given was very good and the learning with ADI model and a contextual approach was very interesting and made the material clearer and easier to understand. The average score of student responses was $83.25 \%$ and fell into very good category; (3) Students' critical thinking skill in grades eight A and $8 \mathrm{~B}$ increased after ADI learning model and contextual approach were applied. This is evidenced by the average N-gain of grade eight $A$ $(0.74)$ with a high category and the average $\mathrm{N}$-gain grade of eight $\mathrm{B}(0.75)$ with a high category. Based on statistical tests on the paired $t$ test conducted on the pre-test and post-test scores, the probability value (sig) was equal to 0,000 . This means that the significance value was $<0.05$ and $t_{\text {count }} \geq t_{\text {table. }}$. Therefore, $\mathrm{H}_{0}$ was rejected and $\mathrm{H}_{1}$ was accepted. Based on the acquisition of the significance value there were differences in the results of students' critical thinking skills in the pre-test and post-test. The development of critical thinking skills through the ADI model with contextual approach is expected to support student to achieve their success in the future. They needed guidance and pedagogical support to become accustomed to critical thinking. Implication of this research is that the ADI model with contextual approach can be an innovative solution to improve critical thinking skills, yet there is still a need for repetition. To strengthen the result of this research, it is necessary to do further research in other relevant material and in various education levels.

\section{ACKNOWLEDGEMENTS}

The author would like to thank the Postgraduate of Surabaya State University for overseeing this research and SMP Negeri 1 Bluto for allowing the authors to retrieve data. 


\section{REFERENCES}

Abdullah, Ridwan. 2013. Inovasi Pembelajaran. Jakarta: Bumi Aksara

Aditomo, A., \& Klieme, E. (2020). Forms of inquiry-based science instruction and their relations with learning outcomes: Evidence from high and low-performing education systems. International Journal of Science Education, 42(4), 504-525. https:// doi.org/10.1080/09500693.2020.1716093

Anderson, L.W. \& Krathwohl, D. R. (2001). A taxonomy for learning, teaching, and assessing. A revision of bloom's taxonomy of educational objectives. Addison Wesley Longman, Inc.

Bathgate, M., Crowell, A., Schunn, C., Cannady, M., \& Dorph, R. (2015). The learning benefits of being willing and able to engage in scientific argumentation. International Journal of Science Education, 37(10), 1590-1612. https:// doi.org/10.1080/09500693.2015.1045958

Chen, H. T., Wang, H. H., Lu, Y. Y., Lin, H. S., \& Hong, Z. R. (2016). Using a modified argumentdriven inquiry to promote elementary school students' engagement in learning science and argumentation. International Journal of Science Education, 38(2), 170-191. https:// doi.org/10.1080/09500693.2015.1134849

Choy, S. C., \& Cheah, P. K. (2009). Teacher perceptions of critical thinking among students and its influence on higher education. International Journal of teaching and learning in Higher Education, 20(2), 198-206.

Darsono, M. 2011. Belajar dan Pembelajaran. Semarang: IKIP Semarang Press

Deane, P., \& Song, Y. (2014). A case study in principled assessment design: Designing assessments to measure and support the development of argumentative reading and writing skills. Psicología Educativa, 20(2), 99-108. https://doi.org/10.1016/j.pse.2014.10.001

Demircioğlu, T., \& Ucar, S. (2012). The effect of argument-driven inquiry on pre-service science teachers' attitudes and argumentation skills. Procedia-Social and Behavioral Sciences, 46, 50355039. https:// doi.org/10.1016/i.sbspro.2012.06.382

Demircioglu, T., \& Ucar, S. (2015). Investigating the effect of argument-driven inquiry in laboratory instruction. Educational Sciences: Theory \& Practice, 15(1). https:// doi.org/10.12738/estp.2015.1.2324

Dori, Y. J., Avargil, S., Kohen, Z., \& Saar, L. (2018). Context-based learning and metacognitive prompts for enhancing scientific text comprehension. International Journal of Science Education, 40(10), 1198-1220. https://doi.org/10.1080/09500693.2018.1470351

Facione, P.A. (2013). Critical thinking: What it is and why it counts. Measured Reasons and the California Academic Press.

Griffin, P. \& Care, E. (2015). Assesment and teaching of 21st century skills: Method and approach. Springer.

Harris, C. J., Phillips, R. S., \& Penuel, W. R. (2012). Examining teachers' instructional moves aimed at developing students' ideas and questions in learner-centered science classrooms. Journal of Science Teacher Education, 23(7), 769-788. https://doi.org/10.1007/s10972-011-9237-0

Hasnunidah, N., Susilo, H., Henie Irawati, M., \& Sutomo, H. (2015). Argument-driven inquiry with scaffolding as the development strategies of argumentation and critical thinking skills of students in Lampung, Indonesia. American Journal of Educational Research, 3(9), 1185-1192.

Kadayifci, H., Atasoy, B., \& Akkus, H. (2012). The correlation between the flaws students define in an argument and their creative and critical thinking abilities. Procedia-Social and Behavioral Sciences, 47, 802-806. https://doi:10.1016/j.sbspro.2012.06.738

Lubben, F., Sadeck, M., Scholtz, Z., \& Braund, M. (2010). Gauging students' untutored ability in argumentation about experimental data: A South African case study. International Journal of Science Education, 32(16), 2143-2166. https:// doi.org/10.1080/09500690903331886

Nufus, H., Undang Rosidin, U. R., \& Hasnunidah, N. (2018). Influence of implementation argument-driven inquiry model to junior high school students' critical thinking skills based on difference of academic ability. Jurnal Pendidikan Fisika, 7(2), 110-117. https:// doi.org/10.22611/jpf.v7i2.11007 
Peşman, H., \& Özdemir, Ö. F. (2012). Approach-method interaction: The role of teaching method on the effect of context-based approach in physics instruction. International Journal of Science Education, 34(14), 2127-2145. https:/ / doi.org/10.1080/09500693.2012.700530

Prastowo, A. (2012). Panduan Kreatif Membuat Bahan Ajar Inovatif. DIVA Press.

Sampson, V., \& Walker, J. P. (2012). Argument-driven inquiry as a way to help undergraduate students write to learn by learning to write in chemistry. International Journal of Science Education, 34(10), 1443-1485. https://doi.org/10.1080/09500693.2012.667581

Schleicher, A. (2019). PISA 2018: Insights and interpretations. OECD Publishing. https://eric.ed.gov/?id=ED601150

Sulistyowati, E. (2014). Metodologi Pembelajaran IPA. Bumi Aksara.

Thiagarajan, S., Semmel, D. S. \& Semmel, M. I. (1974). Instructional Development for Training Teachers of Expectional Children. Council for Exceptional Children.

Van Uum, M. S., Verhoeff, R. P., \& Peeters, M. (2016). Inquiry-based science education: towards a pedagogical framework for primary school teachers. International journal of science education, 38(3), 450-469. http:/ / doi.org/10.1080/09500693.2016.1147660

Yacoubian, H. A., \& Khishfe, R. (2018). Argumentation, critical thinking, nature of science and socio scientific issues: A dialogue between two researchers. International Journal of Science Education, 40(7), 796-807. https://doi.org/10.1080/09500693.2018.1449986

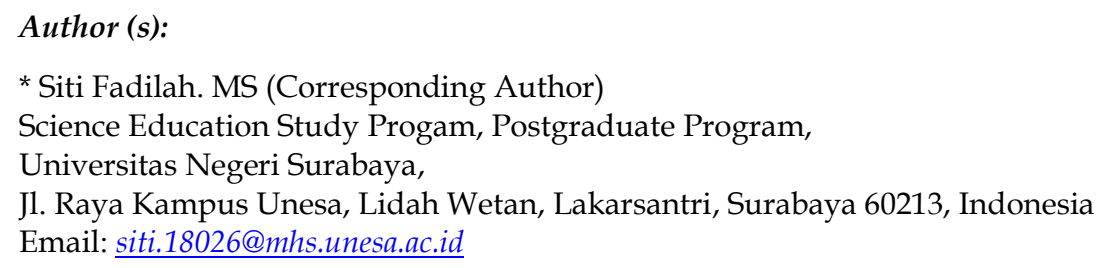

